\title{
Circulating microRNA-636 is associated with the elimination of hepatitis C virus by ombitasvir/paritaprevir/ritonavir
}

\author{
Asahiro Morishita1, Hirohito Yoneyama ${ }^{1}$, Hisakazu Iwama², Koji Fujita1, Miwako \\ Watanabe ${ }^{1}$, Kayo Hirose ${ }^{1}$, Tomoko Tadokoro ${ }^{1}$, Kyoko Oura ${ }^{1}$, Teppei Sakamoto ${ }^{1}$, \\ Shima Mimura ${ }^{1}$, Takako Nomura ${ }^{1}$, Makoto Oryu ${ }^{3}$, Takashi Himoto ${ }^{4}$, Kunitada \\ Shimotohno ${ }^{5}$ and Tsutomu Masaki ${ }^{1}$ \\ ${ }^{1}$ Department of Gastroenterology and Neurology, Ikenobe Miki-cho, Kita-gun, Kagawa 761-0793, Japan \\ ${ }^{2}$ Life Science Research Center, Ikenobe Miki-cho, Kita-gun, Kagawa 761-0793, Japan \\ ${ }^{3}$ Department of Internal Medicine, Kagawa Saiseikai Hospital, Tahikamimachi, Takamatsu, Kagawa 761-8076, Japan \\ ${ }^{4}$ Department of Medical Technology, Kagawa Prefectural University of Health Sciences, Hara, Mure-cho, Takamatsu, Kagawa \\ 761-0123, Japan \\ ${ }^{5}$ Research Center for Hepatitis and Immunology, National Center for Global Health and Medicine, Kohnodai, Ichikawa, Chiba \\ 272-8516, Japan \\ Correspondence to: Asahiro Morishita, email: asahiro@med.kagawa-u.ac.jp \\ Keywords: circulating microRNA; microRNA-636; ombitasvir/paritaprevir/R; HCV elimination; direct-acting antiviral \\ Received: May 22, $2018 \quad$ Accepted: July 13, $2018 \quad$ Published: August 10, 2018 \\ Copyright: Morishita et al. This is an open-access article distributed under the terms of the Creative Commons Attribution License \\ 3.0 (CC BY 3.0), which permits unrestricted use, distribution, and reproduction in any medium, provided the original author and \\ source are credited.
}

\section{ABSTRACT}

Hepatitis C virus (HCV) infection causes sustained inflammation and fibrosis. Several oral direct-acting antivirals (DAAs) including ombitasvir/paritaprevir/ritonavir (OBV/PTV/r) were recently developed for HCV elimination. The combination of DAAs brought a higher sustained viral response (SVR) rate to anti-HCV therapy compared to interferon (IFN)-based regimens. However, $5 \%$ of hepatitis $C$ patients who undergo DAA therapy still suffer from a sustained HCV infection. MicroRNA (miRNA) is essentially interfering, endogenous noncoding RNA that has been investigated as a new biomarker for the response to DAA in hepatitis $C$ patients. Here we used a miRNA array and real-time polymerase chain reaction (PCR) to determine the targetable miRNA before and 12 weeks after OBV/PTV/r treatment for refractory hepatitis $C$. We used replicon cells, in which genotype 1b type HCV is stably transfected in Huh7 cells, to determine whether miRNA can inhibit HCV replication. Among 2,555 miRNAs, three were significantly up-regulated and eight miRNAs were down-regulated in serum 12 weeks after OBV/PTV/ $r$ treatment. An unsupervised hierarchical clustering analysis, using Pearson's correlation, showed that the miRNA profiles between before and 12 weeks after OBV/PTV/r treatment were clustered separately. At 12 weeks after OBV/PTV, miR-636 was targeted among the eight down-regulated miRNAs, and the expression level of circulating miR-636 was significantly diminished. The amount of HCV-RNA was significantly diminished 48 hours after miR-636 inhibitor transfection in HCV replicon cells. In conclusion, miR-636 might be one of the essential targetable molecules in HCV patients who undergo DAA therapy and still suffer from a sustained HCV infection.

\section{INTRODUCTION}

Hepatitis $\mathrm{C}$ virus (HCV) is one of the most damaging viruses $[1,2]$, and its chronic infection causes sustained inflammation and fibrosis [3, 4]. Until recently, interferon (IFN)-based regimens had been used to treat $\mathrm{HCV}$ infection, and anti-HCV therapy was restricted due to its severe side effects, resulting in a poor cure rate $[5,6]$. Several oral direct-acting antivirals (DAAs) for $\mathrm{HCV}$ elimination were developed over the last several 
years [7-10]. The combination of DAAs brought a revolutionary improvement to anti-HCV therapy. Twelveweek DAA combination therapy eliminates HCV with very high probability and without noticeable side effects. The sustained viral response (SVR) rate in chronic HCV genotype $1 \mathrm{~b}$ (HCV GT-1b) infection is now reported to be $95 \%-100 \%$ [10]. However, approx. 5\% of HCV patients who undergo DAA therapy still suffer from a sustained $\mathrm{HCV}$ infection.

Ombitasvir, dosed once daily, is an HCV NS5A inhibitor that acts by inhibiting the HCV protein NS5A. Paritaprevir, an $\mathrm{HCV}$ NS3/4A protease inhibitor that decreases the expression of $\mathrm{HCV} \mathrm{NS} 3 / 4 \mathrm{~A}$ protein, is administered with low-dose ritonavir (paritaprevir/ ritonavir) to enhance the patient's paritaprevir plasma levels and prolong its half-life. Both ombitasvir and paritaprevir have powerful in vitro antiviral activity for multiple subtypes of $\mathrm{HCV}$, including $1 \mathrm{a}, 1 \mathrm{~b}, 2 \mathrm{a}, 2 \mathrm{~b}, 3 \mathrm{a}$, $4 \mathrm{a}$, and $6 \mathrm{a}$. A randomized phase III trial of $\mathrm{OBV} / \mathrm{PTV} / \mathrm{r}$ revealed that the SVR rate at 12 weeks post-treatment was $94.9 \%$ in HCV genotype 1b-infected patients [8]. However, virological failure occurred in $3.0 \%$ of the $\mathrm{HCV}$ patients treated with $\mathrm{OBV} / \mathrm{PTV} / \mathrm{r}$ in that trial [8]. In order to reduce the virological failure rate, it is important to determine the precise mechanisms that underlie the elimination of $\mathrm{HCV}$ by OBV/PTV/r directly and indirectly, including the regulation of miRNA in host cells.

MicroRNAs (miRNAs) are essentially 18-22-nucleotide-long, interfering, endogenous noncoding RNAs, and more than one thousand of miRNAs have been discovered in the human genome [11]. The effect of miRNAs on the regulation of the expression of various genes is so broad that one miRNA promotes the targeting and modulation of $>200$ genes [12]. The HCV genome is a positive-sense, single-stranded RNA with a conserved 5' noncoding region (NCR), one open reading frame (ORF) and a conserved 3'-NCR. The single ORF encodes a polyprotein, and its $\mathrm{N}$ terminus is cleaved by endoplasmic reticulum (ER) signal peptidase and/or signal peptide peptidase (SPP) into three structural proteins (core, E1, and E2) [13]. The other sequence of the polyprotein is processed by the viral NS2 and/or NS3/4A protease into seven nonstructural proteins (p7, NS2, NS3, NS4A, NS4B, NS5A and NS5B), which play important roles in the HCV life cycle [14].

Interestingly, the $\mathrm{HCV}$ genome does not encode viral miRNA $[15,16]$. However, HCV infection alters the expression of host miRNAs during the progression of liver disease such as liver fibrosis, cirrhosis, and hepatocellular carcinoma [17-20]. In fact, host miRNAs control the HCV life cycle by directly binding to HCV RNAs or indirectly targeting cellular mRNAs [13]. Increasing evidence indicates that miRNAs are one of the centered factors in the interaction network between a virus and a host [13]. In addition, HCV RNA segregates host miRNAs from their normal host targets and reduces host gene expression, resulting in a persistent $\mathrm{HCV}$ infection [21]. This interference by HCV RNA might be a key to elucidate the mechanism of $\mathrm{HCV}$ elimination by $\mathrm{OBV} / \mathrm{PTV} / \mathrm{r}$.

Therefore, the modulation of miRNAs, which are associated with the elimination process by $\mathrm{OBV} / \mathrm{PTV} / \mathrm{r}$, might be valuable therapeutic targets in anti-HCV therapy. In this study, we identified the targetable miRNAs which are related to the $\mathrm{HCV}$ elimination process brought about by $\mathrm{OBV} / \mathrm{PTV} / \mathrm{r}$.

\section{RESULTS}

\section{Sample characteristics}

As shown in Table 1, 11 males and seven females were characterized. Of these, nine patients were $\leq 70$ and nine patients were $>70$ years old (mean: $70.5 \pm 8.3$ yrs). Thirteen of the HCV-positive patients had chronic hepatitis, and five of them had liver cirrhosis as a histological background. Among the 18 patients with chronic hepatitis $\mathrm{C}$, the ALT levels were $\leq 40 \mathrm{IU} / \mathrm{L}$ in 14 patient and $>40 \mathrm{IU} / \mathrm{L}$ in four patients (mean: $70.5 \pm 8.3$ IU/L). The estimated glomerular filtration rate (eGFR) was $<30 \mathrm{~mL} / \mathrm{min} / 1.73 \mathrm{~m}^{2}$ in six patients, $30-50 \mathrm{~mL} /$ $\mathrm{min} / 1.73 \mathrm{~m}^{2}$ in four patients, and $>50 \mathrm{~mL} / \mathrm{min} / 1.73 \mathrm{~m}^{2}$ in eight patients (mean: $37.1 \pm 26.1$ ). Nine patients showed $<6$ HCV RNA, and nine patients showed $\geq 6$ HCV RNA (log $\mathrm{IU} / \mathrm{mL}$, mean $6.0 \pm 0.5)$.

\section{Response to OBV/PTV/r treatment}

Of the 18 patients who received OBV/PTV/r treatment, 17 had serum samples collected for miRNA analysis at time points before and at week 4 , week 6 , and week 12 (One serum sample, which is from relapse case was excluded). All patients were infected with $\mathrm{HCV}$ genotype 1 with no genetic mutation in NS5A lesion. The sustained virological response rate at 4 weeks after the start of treatment $\left(\mathrm{SVR}_{4}\right)$ was $94.4 \%$, and that at 6 weeks $\left(\mathrm{SVR}_{6}\right.$ ) of treatment was $100 \%$ (Figure $\left.1 \mathrm{~A}\right)$. The $\mathrm{SVR}_{12}$ was $94.4 \%$ in the treatment-naïve patients who received OBV/PTV/r treatment (Figure $1 \mathrm{~A}$ ). In addition, the normalization rates of ALT after 4 weeks and 6 weeks were $83.3 \%$ and $88.9 \%$, respectively (Figure 1B). One patient experienced a grade 4 side effect at week 8 and failed to complete the OBV/PTV/r treatment (Figure 1A).

\section{Differences in miRNA in the serum samples obtained between before and after $\mathrm{OBV} / \mathrm{PTV} / \mathrm{r}$ treatment}

Using a custom microarray platform, we analyzed the expression levels of 2,555 human miRNA probes in the patients' serum samples obtained before and after the start of OBV/PTV/r treatment. As shown in Figure 2, Table 2, and Table 3, our comparison of the expression of miRNAs in serum samples between before and after the start of 
Age (year, mean 70.5 \pm 8.3 ):

$\begin{array}{ll}\leq 70 & 9 \\ >70 & 9\end{array}$

Sex:

$\begin{array}{ll}\mathrm{F} & 7\end{array}$

M

Histological background:

$\mathrm{CH}$

LC

ALT (IU/L, mean 70.5 \pm 8.3 ):

$\leq 40$

$>40$

eGFR (mL/min/1.73 m2, mean 37.1 26.1$)$ :

$<30$

30-50

HCV-RNA (Log IU/mL, mean 6.0 \pm 0.5 ):

$<6$

\section{A}

HCV-RNA after OBV/PTV/r administration

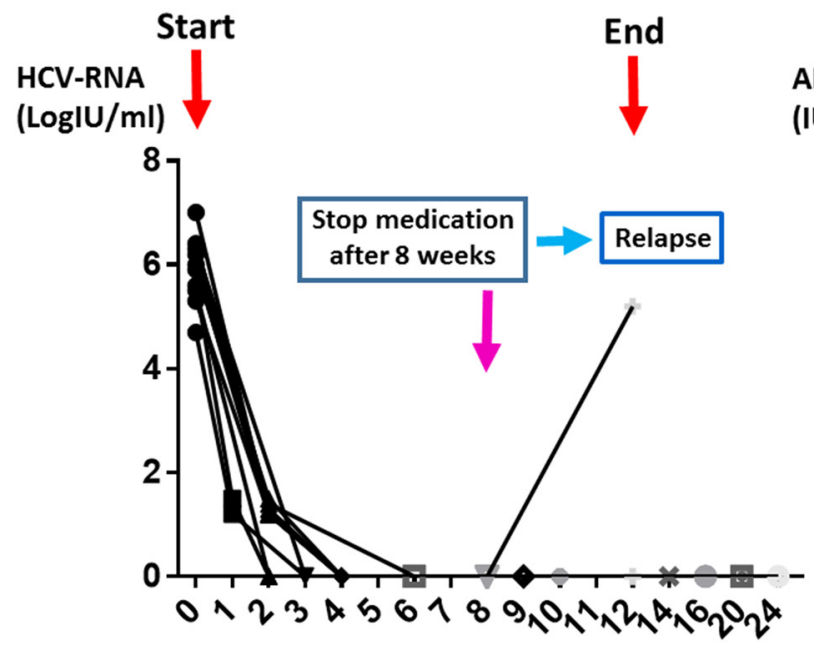

(W)
B

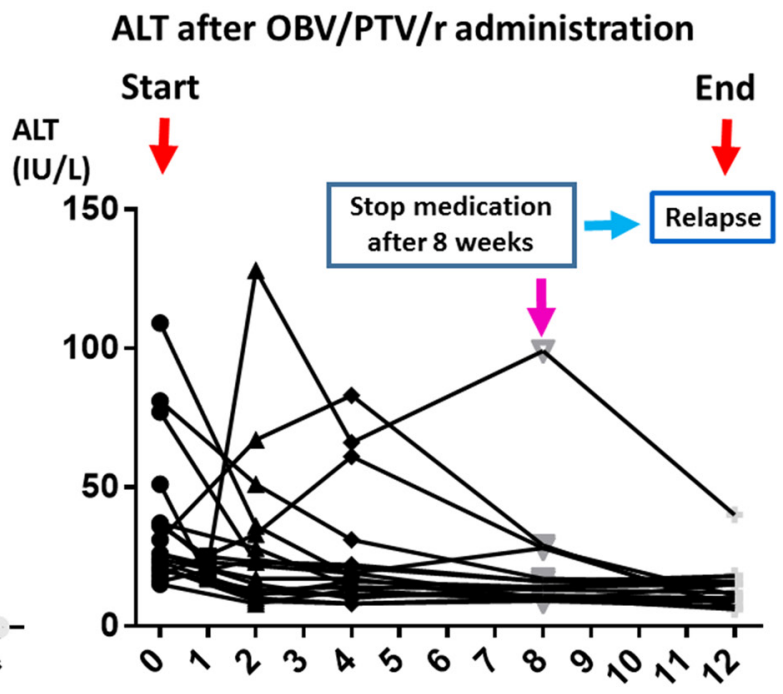

(W)

Figure 1: Clinical features during OBV/PTV/r treatment. (A) Changes in the amount of HCV-RNA during OBV/PTV/r treatment. (B) Changes in the level of ALT during OBV/PTV/r treatment. One patient experienced a grade 4 side effect at week 8 and failed to complete the OBV/PTV/r treatment. 
$\mathrm{OBV} / \mathrm{PTV} / \mathrm{r}$ treatment revealed that at 12 weeks after the start of OBV/PTV/r treatment, of the 2,555 miRNAs just three miRNAs were significantly up-regulated in the sera (Figure 2, Table 2) and eight were down-regulated (Figure 2, Table 3). The unsupervised hierarchical clustering analysis using Pearson's correlation showed that miRNA profiles between before and at 12 weeks after the start of $\mathrm{OBV} / \mathrm{PTV} / \mathrm{r}$ treatment were clustered separately (Figure 2).

\section{Circulating miR-636 expression in serum is down-regulated 12 weeks after the start of $\mathrm{OBV} / \mathrm{PTV} / \mathrm{r}$ treatment}

To elucidate the target miRNA related to the elimination of $\mathrm{HCV}$ by $\mathrm{OBV} / \mathrm{PTV} / \mathrm{r}$, we targeted miR-
636 among the eight down-regulated miRNAs. We determined the expression level of circulating miR-636 using serum samples and real time RT-PCR at time points before and at week 4 and week 12 after the start of OBV/ $\mathrm{PTV} / \mathrm{r}$ treatment. Remarkably, miR-636 was significantly diminished 12 weeks after the start of OBV/PTV/r treatment (Figure 3).

\section{Inhibition of miR-636 reduces HCV RNA replication}

Our in vivo study led us to hypothesize that OBV/ $\mathrm{PTV} / \mathrm{r}$ might inhibit $\mathrm{HCV}$ replication via miR-636 down-regulation. To examine this hypothesis, we used replicon cells, with which genotype $1 \mathrm{~b}$ type $\mathrm{HCV}$ is

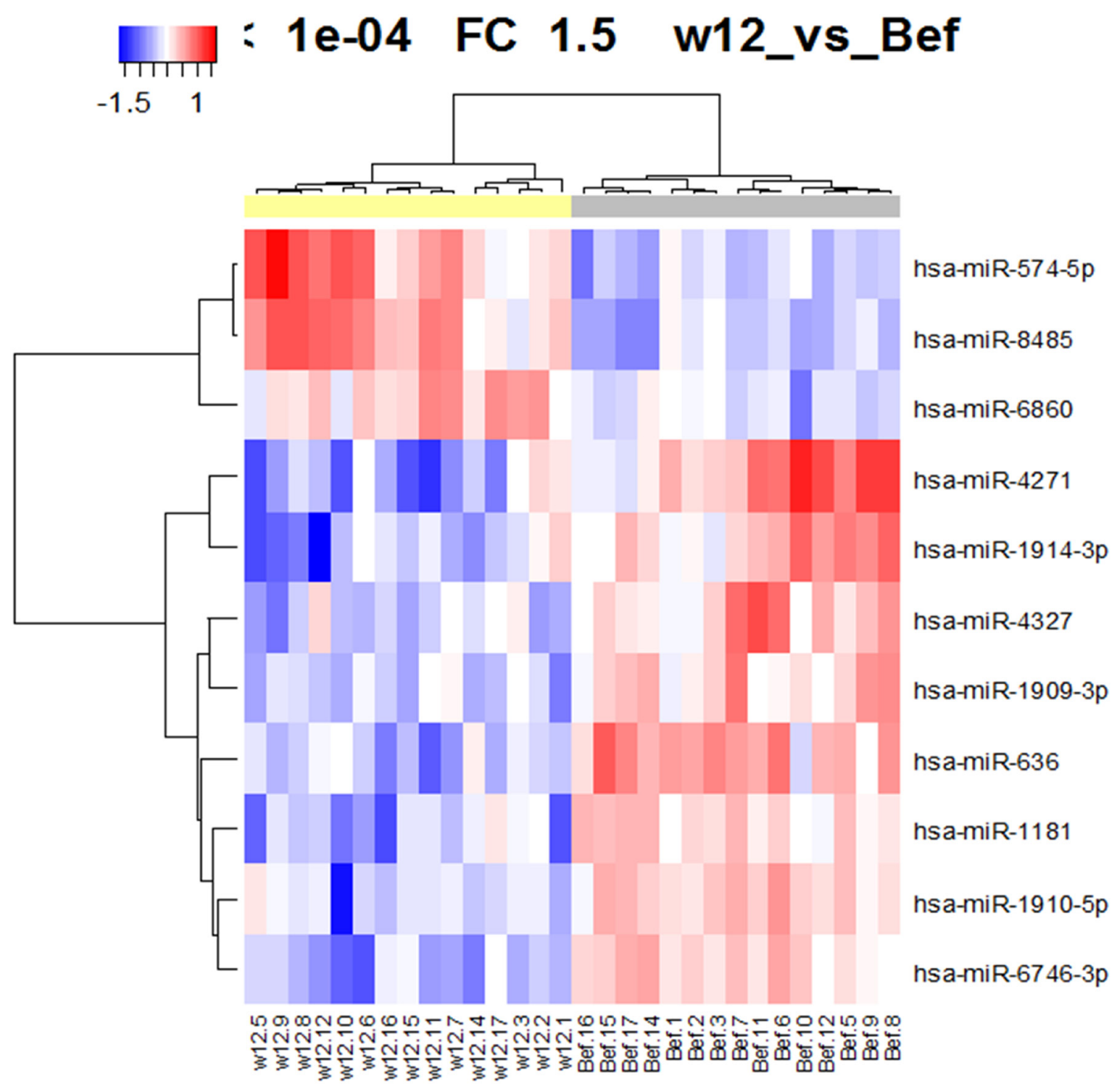

Figure 2: Hierarchical clustering of the 11 miRNAs expressed between before and 12 weeks after the start of OBV/ PTV/r treatment $(\mathbf{p}<0.0001)$. 
Table 2: Three microRNAs were significantly up-regulated 12 weeks after OBV/PTV/r administration (p<0.0001)

\begin{tabular}{lccc}
\hline & P-value & FC (W12/Bef) & FDR \\
\hline hsa-miR-574-5p & $9.0 \mathrm{E}-08$ & 2.10 & $2.7 \mathrm{E}-05$ \\
hsa-miR-8485 & $8.2 \mathrm{E}-06$ & 2.05 & $7.0 \mathrm{E}-04$ \\
hsa-miR-6860 & $6.3 \mathrm{E}-05$ & 1.51 & $1.9 \mathrm{E}-03$ \\
\hline
\end{tabular}

Table 3: Eight microRNAs were significantly down-regulated 12 weeks after OBV/PTV/r administration (p<0.0001)

\begin{tabular}{lccc}
\hline & p-value & FC (W12/Bef) & FDR \\
\hline hsa-miR-6746-3p & $5.2 \mathrm{E}-08$ & 0.58 & $2.7 \mathrm{E}-05$ \\
hsa-miR-1181 & $1.3 \mathrm{E}-06$ & 0.63 & $1.9 \mathrm{E}-04$ \\
hsa-miR-1910-5p & $5.6 \mathrm{E}-06$ & 0.65 & $6.0 \mathrm{E}-04$ \\
hsa-miR-1914-3p & $1.2 \mathrm{E}-05$ & 0.54 & $8.0 \mathrm{E}-04$ \\
hsa-miR-636 & $1.2 \mathrm{E}-05$ & 0.51 & $8.0 \mathrm{E}-04$ \\
hsa-miR-1909-3p & $3.0 \mathrm{E}-05$ & 0.64 & $1.6 \mathrm{E}-03$ \\
hsa-miR-4271 & $6.2 \mathrm{E}-05$ & 0.45 & $1.9 \mathrm{E}-03$ \\
hsa-miR-4327 & $8.1 \mathrm{E}-05$ & 0.59 & $2.1 \mathrm{E}-03$ \\
\hline
\end{tabular}

stably transfected in Huh7 cells [22]. Replicon cells were transfected with miR-636 mimic, miR-636 inhibitor, or negative control miRNA. After 24 hour and 48 hour incubations, we analyzed the miR-636 and HCV RNA. Interestingly, the amount of HCV RNA was significantly diminished 48 hour after miR-636 inhibitor transfection (Figure 4B), which is in consistent with the inhibition of miR-636 (Figure 4B), although no remarkable reduction of HCV RNA was detected 24 hour after miR-636 inhibitor transfection (Figure 4B). On the other hand, the HCV
RNA level was not influenced by miR-636 overexpression at 24 hour or 48 hour after miR-636 mimic transfection (Figure 4B).

\section{DISCUSSION}

HCV genotyping is a major cause of DAA treatment failure [23]. DAAs inhibit various parts of $\mathrm{HCV}$ protein including NS3/4A, NS5A, and NS5B protein. Gene

\section{Serum miR-636 expression after OBV/PTV/r administration}

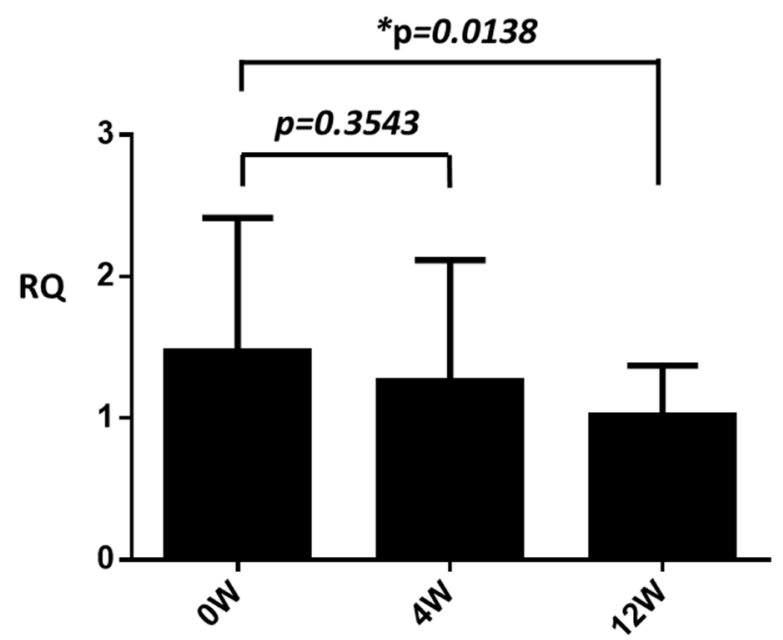

Figure 3: Serum miR-636 expression before, 4 weeks, and 12 weeks after the start of OBV/PTV/r treatment. miR-636 was significantly diminished after 12 weeks compared to before OBV/PTV/r treatment. " $\mathrm{p}<0.05$. 
mutations of these loci lead to the treatment failure by different types of DAAs. As virological failure occurred in $3.0 \%$ of $\mathrm{HCV}$ patients treated with $\mathrm{OBV} / \mathrm{PTV} / \mathrm{r}$ [8], $\mathrm{HCV}$ NS5A and HCV NS3/4A mutations may exist in OBV/ $\mathrm{PTV} / \mathrm{r}$-failure patients. It is refractory for the patients with mutant HCV to eliminate HCV by OBV/PTV/r therapy.

Liver-specific miRNA miR-122 or interference of the RNA interference pathway associated with miRNA biogenesis resulted in the inhibition of HCV replication [24]. Circulating miRNAs (cmiRNAs) in the plasma or serum have been assessed for evaluations of the therapeutic response and antiviral effects in patient with hepatitis $\mathrm{C}$, since cmiRNAs are protected from RNase and stabilized even in the serum $[23,25,26]$. Therefore, toward the goal of reducing the virological failure rate of DAA treatment, we examined targetable miRNAs during HCV elimination by $\mathrm{OBV} / \mathrm{PTV} / \mathrm{r}$. Our analyses revealed three up-regulated miRNAs and eight down-regulated miRNAs at 12 weeks after the start of $\mathrm{OBV} / \mathrm{PTV} / \mathrm{r}$ treatment. Among these
miRNAs, miR-636 was significantly reduced by 12 weeks of $\mathrm{OBV} / \mathrm{PTV} / \mathrm{r}$ treatment in the serum of $\mathrm{HCV}$ patients. Additionally, a time-lag was observed between $\mathrm{HCV}$ elimination and miR-636 down-regulation (Figure 3).

These results indicate that miR-636 might be involved in not only $\mathrm{HCV}$ elimination but also liver regeneration. Jang et al. demonstrated that a downregulation of miR-636 is associated with cell proliferation through an enhanced expression of Ras, which is one of the putative targets of miR-636 [27]. In addition, ANT2 suppression restores mi-636 expression, thereby downregulating RAS and inhibiting cell proliferation [27]. On the other hand, miR-636 reduction is involved in the recovery from heart failure due to dilated cardiomyopathy [28]. These reports support our finding that miR-636 is related to the process of $\mathrm{HCV}$ elimination and recovers liver function, normalizing ALT.

To explore the functions of miR-636, we examined whether miR-636 is involved in the inhibition of $\mathrm{HCV}$

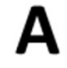

\section{Structure of the HCV(G1b) genomic replicon}

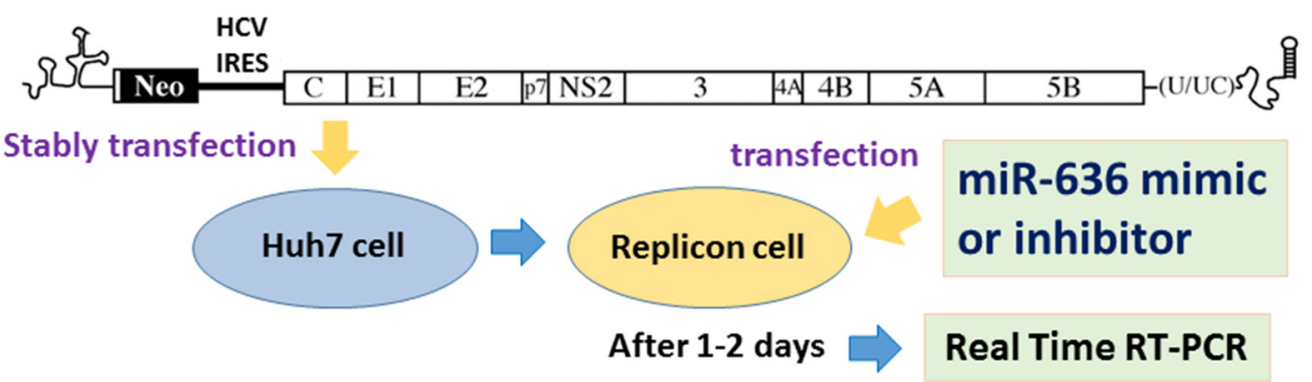

B HCV-RNA $24 \mathrm{hrs}$ after transfection

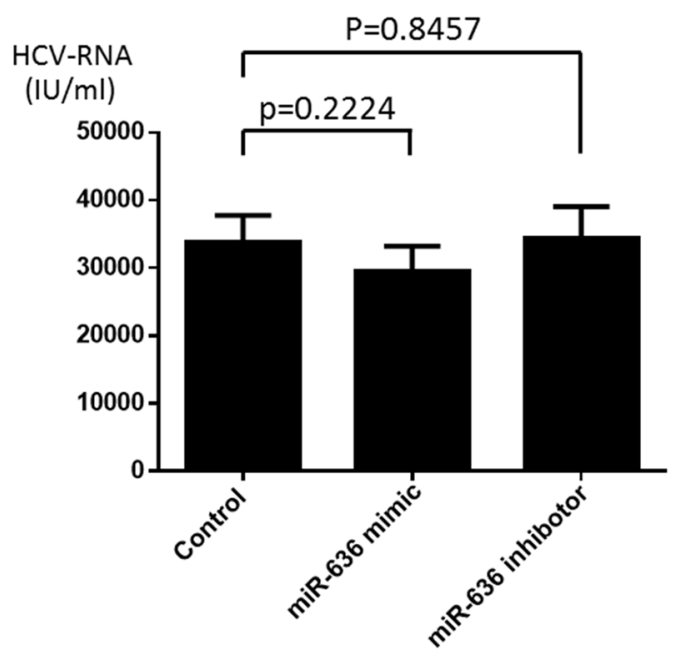

HCV-RNA 48 hrs after transfection

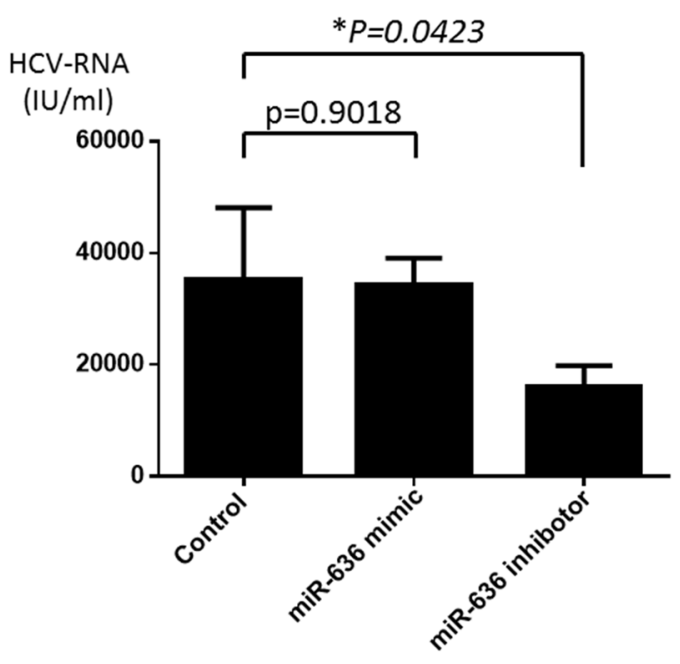

Figure 4: Loss of miR-636 expression reduced the HCV-RNA replication in Huh7 cells with HCV GT-1b genomic replicon. (A) Schematic of the structure of the HCV GT-1b genomic replicon. (B) The amount of HCV-RNA at 24 and 48 hours after miR-636 mimic and inhibitor transfection. 
replication during $\mathrm{OBV} / \mathrm{PTV} / \mathrm{r}$ treatment, and whether miR-636 is suppressed as a result of HCV elimination by $\mathrm{OBV} / \mathrm{PTV} / \mathrm{r}$ treatment. We transfected replicon cells with miR-636 mimic and miR-636 inhibitor and then analyzed the HCV-RNA expression by real-time PCR. The expression level of HCV-RNA was significantly downregulated by miR-636 inhibition (Figure 4B). We also examined the miR-636 expression at week 4 and 6 , and miR-636 expression was gradually reduced as compared to before OBV/PTV/r treatment (data not shown). These results suggest that miR-636 can suppress HCV replication and its inhibitor might be a powerful antiviral drug for patients with refractory mutant $\mathrm{HCV}$. In addition, in Figure $4 \mathrm{~B}$, inhibition of miR-636 reduced amount of HCV-RNA at 48 hour, but not at 24 hour after miR-636 inhibitor transfection. There was a time-lag between miR-636 inhibitor transfection and reduction of HCV-RNA level. Interestingly, there is no homology between miR-636 and the 5'-UTR sequences of HCV, and thus miR-636 might regulate key molecules for $\mathrm{HCV}$ elimination in host cells. These indicate that miR-636 have indirect inhibitory effect on HCV replication.

It was already demonstrated that the inhibition of some miRNAs including miR-199a-5p reduces the replication of $\mathrm{HCV}$ via regulation of the pro-survival pathway and not a direct interaction between miRNA and HCV [29]. Some of HCV host factors, including CHUK, IKK- $\alpha$, and I $\mathrm{KB}$ kinase, are regulated by let-7a and therefore, let-7a indirectly mediates antiviral effects [30]. In addition, miR-25 and miR-130 families repress various $\mathrm{HCV}$ co-factors and inhibit viral infection and replication at multiple steps [30]. These reports support our data that some miRNAs can modulate $\mathrm{HCV}$ replication even through indirect inhibition.

Taken together, our present findings revealed that miR-636 expression is reduced in the sera of $\mathrm{HCV}$ patients at 12 weeks after the start if OBV/PTV/r treatment, and the loss of miR-636 expression inhibits HCV replication in human hepatocellular carcinoma cells. Therefore, miR636 might play an important role as a powerful therapeutic target for $\mathrm{HCV}$ elimination and liver regeneration.

In conclusion, miR-636 is associated with the elimination process of $\mathrm{OBV} / \mathrm{PTV} / \mathrm{r}$ treatment, and it might be one of the essential targetable molecules in $\mathrm{HCV}$ patients who undergo DAA treatment and still suffer from a sustained HCV infection.

\section{PATIENTS AND METHODS}

\section{Patients}

This study enrolled 18 HCV GT-1b-infected hepatitis patients who had undergone OBV/PTV/r (OBV 25mg/day, PTV $150 \mathrm{mg} /$ day, r $100 \mathrm{mg} /$ day) oral administration for 12 weeks at Kagawa University Hospital (Kita-gun, Kagawa, Japan) between 2015 and 2017.

\section{The miRNA microarray for HCV GT-1b-infected serum}

Each patient's serum sample was processed for total RNA extraction with the miRNeasy Mini Kit (Qiagen, Venlo, Netherlands) according to the manufacturer's instructions. The RNA samples typically showed $A_{260 / 280}$ ratios of between 1.9 and 2.1, as shown by an Agilent 2100 Bioanalyzer (Agilent Technologies, Santa Clara, CA).

After RNA measurement with an RNA 6000 Nano kit (Agilent Technologies), the samples were labeled using a miRCURY Hy3/Hy5 Power labeling kit (Exiqon, Vedbaek, Denmark) and were hybridized on a human miRNA Oligo chip10, ver. 14.0 (Toray Industries, Tokyo). Scanning was conducted with a 3D-Gene Scanner 3000 (Toray). We used 3D-Gene extraction ver. 1.2 software (Toray) to read the raw intensity of the image. To determine the change in miRNA expression, we analyzed the raw data via GeneSpringGX ver. 10.0 (Agilent Technologies). All samples were frozen at $-80{ }^{\circ} \mathrm{C}$ within $4 \mathrm{hr}$ of collection and thawed just before analysis.

\section{Real time RT-PCR for quantifying circulating miRNA}

Circulating miRNA was extracted from $200 \mu \mathrm{l}$ of serum sample using the Qiagen miRNeasy serum-plasma kit (Qiagen, Tokyo) according to the manufacturer's instructions. RNA was reverse transcribed using TaqMan MicroRNA Reverse Transcription kit (Life Technologies Japan, Tokyo). Caenorhabditis elegans miR-39 (cel-miR-39) was spiked in each sample as a control for the extraction and amplification steps. Serum miRNA was amplified using primers and probes provided by Applied Biosystems (Foster City, CA, USA) by the TaqMan MicroRNA assay, according to the manufacturer's instructions. We calculated the relative expression of serum miRNA using the comparative cycle threshold (CT) method (2- $\left.2^{-\Delta \Delta C T}\right)$ with spiked cel-miR-39 as a normalized internal control.

\section{Cell culture}

The human hepatocellular carcinoma cell line Huh7 was obtained from the Japanese Collection of Research Bioresources (JCRB) Cell Bank and transported to our laboratory. The Huh7 cell line was authenticated by the JCRB Cell Bank using short tandem repeat polymerase chain reaction (PCR). All cell lines were grown in RPMI1640 medium (Gibco Invitrogen, Carlsbad, CA, USA) supplemented with $10 \%$ fetal bovine serum (FBS) and penicillin-streptomycin $(100 \mathrm{mg} / \mathrm{L}$; Invitrogen $)$ at $37^{\circ} \mathrm{C}$ in a humidified atmosphere containing $5 \% \mathrm{CO}_{2}$.

\section{Gene transfection}

HCV genomic replicon was stably transfected into Huh-7 cells (NNC\#2 cells). The gene transfection miR- 
636 mimic, the miR-636 inhibitor, and negative control miRNA were obtained from Thermo Scientific (Waltham, MA, USA). Huh-7 NNC\#2 cells were seeded in sixwell plates. After $24 \mathrm{hr}$, the Huh-7 NNC\#2 cells were transfected with the miR-636 mimic, miR-636 inhibitor, or negative control miRNA at a final concentration of 10 nM using Lipofectamine RNAiMAX (Invitrogen, Grand Island, NY, USA). After 24 hour and 48 hour incubations, the cells were harvested and washed with ice-cold phosphate-buffered saline (PBS) for subsequent analysis.

\section{Statistical analysis}

Replicate data were consolidated into two groups: those from serum samples obtained before OBV/PTV/r treatment, and those from serum samples obtained after $\mathrm{OBV} / \mathrm{PTV} / \mathrm{r}$ treatment. Those data were organized by using the hierarchical clustering functions in the GeneSpring software. Hierarchical clustering was done by the use of the clustering function (condition tree) and Pearson's correlation as a distance metric. We conducted a U-test and regarded p-value $<0.0001$ as a significant difference for the array analysis to search for the miRNAs that varied most prominently across the groups. Only changes $>50 \%$ for at least one of the time points for each sample were considered significant. All of the analyzed data were scaled by global normalization. The statistical significance of differentially expressed miRNAs was analyzed by Student's t-test. All analyses were conducted using computer-assisted JMP8.0 (SAS Institute, Cary, NC, USA). A paired analysis between the groups was conducted using Student's t-test. A p-value $<0.05$ was considered to indicate a significant difference between groups.

\section{Abbreviations}

ALT: alanine aminotransferase, DAA: direct-acting antiviral agent, GT-1b: genotype $1 \mathrm{~b}, \mathrm{HCV}$ : hepatitis $\mathrm{C}$ virus, OBV: ombitasvir, PTV: paritaprevir, R: ritonavir, miR-636: microRNA-636, cel-miR-39: cel-microRNA-39, RQ: relative quantification.

\section{Author contributions}

Outpatient service, obtaining informed consent and sample preservation were performed by AM, HY, KF, TT, KO, TS, TN, MO, TH, and TM. Clinical data were summarized by AM. Serum miRNAs were analyzed by HI, $\mathrm{MW}, \mathrm{KH}$ and SM. In vitro experiments were performed by AM, MW, KH, KS. Manuscripts were written by AM, and reviewed by $\mathrm{TH}$, and $\mathrm{TM}$.

\section{ACKNOWLEDGMENTS}

We thank Ms. Fuyuko Kokado, and Ms. Keiko Fujikawa for their skillful technical assistance.

\section{CONFLICTS OF INTEREST}

The authors declare there are no conflicts of interest.

\section{REFERENCES}

1. Seeff LB. Natural history of chronic hepatitis C. Hepatology. 2002; 36: S35-46. https://doi.org/10.1053/ jhep.2002.36806.

2. Hoofnagle JH. Course and outcome of hepatitis C. Hepatology. 2002; 36: S21-9. https://doi.org/10.1053/ jhep.2002.36227.

3. Casiraghi MA, De Paschale M, Romano L, Biffi R, Assi A, Binelli G, Zanetti AR. Long-term outcome (35 years) of hepatitis $\mathrm{C}$ after acquisition of infection through mini transfusions of blood given at birth. Hepatology. 2004; 39 : 90-6. https://doi.org/10.1002/hep.20030.

4. Forner A, Llovet JM, Bruix J. Hepatocellular carcinoma. Lancet. 2012; 379: 1245-55. https://doi.org/10.1016/ S0140-6736(11)61347-0.

5. Raison CL, Demetrashvili M, Capuron L, Miller AH. Neuropsychiatric adverse effects of interferon-alpha: recognition and management. CNS Drugs. 2005; 19: 105-23.

6. Capuron L, Gumnick JF, Musselman DL, Lawson DH, Reemsnyder A, Nemeroff CB, Miller AH. Neurobehavioral effects of interferon-alpha in cancer patients: phenomenology and paroxetine responsiveness of symptom dimensions. Neuropsychopharmacology. 2002; 26: 643-52. https://doi.org/10.1016/S0893-133X(01)00407-9.

7. Omata M, Nishiguchi S, Ueno Y, Mochizuki H, Izumi N, Ikeda F, Toyoda H, Yokosuka O, Nirei K, Genda T, Umemura T, Takehara T, Sakamoto N, et al. Sofosbuvir plus ribavirin in Japanese patients with chronic genotype $2 \mathrm{HCV}$ infection: an open-label, phase 3 trial. J Viral Hepat. 2014; 21: 762-8. https://doi.org/10.1111/jvh.12312.

8. Kumada H, Chayama K, Rodrigues L Jr, Suzuki F, Ikeda K, Toyoda H, Sato K, Karino Y, Matsuzaki Y, Kioka K, Setze C, Pilot-Matias T, Patwardhan M, et al. Randomized phase 3 trial of ombitasvir/paritaprevir/ritonavir for hepatitis $\mathrm{C}$ virus genotype 1b-infected Japanese patients with or without cirrhosis. Hepatology. 2015; 62: 1037-46. https:// doi.org/10.1002/hep.27972.

9. Kumada H, Suzuki Y, Ikeda K, Toyota J, Karino Y, Chayama K, Kawakami Y, Ido A, Yamamoto K, Takaguchi K, Izumi N, Koike K, Takehara T, et al. Daclatasvir plus asunaprevir for chronic HCV genotype 1b infection. Hepatology. 2014; 59: 2083-91. https://doi.org/10.1002/hep.27113.

10. Mizokami M, Yokosuka O, Takehara T, Sakamoto N, Korenaga M, Mochizuki H, Nakane K, Enomoto H, Ikeda F, Yanase M, Toyoda H, Genda T, Umemura T, et al. Ledipasvir and sofosbuvir fixed-dose combination with and without ribavirin for 12 weeks in treatment-naive and previously treated Japanese patients with genotype 1 
hepatitis C: an open-label, randomised, phase 3 trial. Lancet Infect Dis. 2015; 15: 645-53. https://doi.org/10.1016/ S1473-3099(15)70099-X.

11. Zamore PD, Haley B. Ribo-gnome: the big world of small RNAs. Science. 2005; 309: 1519-24. https://doi. org/10.1126/science. 1111444 .

12. Krek A, Grun D, Poy MN, Wolf R, Rosenberg L, Epstein EJ, MacMenamin P, da Piedade I, Gunsalus KC, Stoffel M, Rajewsky N. Combinatorial microRNA target predictions. Nat Genet. 2005; 37: 495-500. https://doi.org/10.1038/ ng1536.

13. Li H, Jiang JD, Peng ZG. MicroRNA-mediated interactions between host and hepatitis C virus. World J Gastroenterol. 2016; 22: 1487-96. https://doi.org/10.3748/wjg.v22.i4.1487.

14. Suzuki T, Ishii K, Aizaki H, Wakita T. Hepatitis C viral life cycle. Adv Drug Deliv Rev. 2007; 59: 1200-12. https://doi. org/10.1016/j.addr.2007.04.014.

15. Skalsky RL, Cullen BR. Viruses, microRNAs, and host interactions. Annu Rev Microbiol. 2010; 64: 123-41. https:// doi.org/10.1146/annurev.micro.112408.134243.

16. Fukuhara T, Matsuura Y. Role of miR-122 and lipid metabolism in HCV infection. J Gastroenterol. 2013; 48: 169-76. https://doi.org/10.1007/s00535-012-0661-5.

17. Ramachandran S, Ilias Basha H, Sarma NJ, Lin Y, Crippin JS, Chapman WC, Mohanakumar T. Hepatitis C virus induced miR200c down modulates FAP-1, a negative regulator of Src signaling and promotes hepatic fibrosis. PLoS One. 2013; 8: e70744. https://doi.org/10.1371/journal. pone.0070744.

18. Ogawa T, Enomoto M, Fujii H, Sekiya Y, Yoshizato K, Ikeda K, Kawada N. MicroRNA-221/222 upregulation indicates the activation of stellate cells and the progression of liver fibrosis. Gut. 2012; 61: 1600-9. https://doi. org/10.1136/gutjnl-2011-300717.

19. Bandyopadhyay S, Friedman RC, Marquez RT, Keck K, Kong B, Icardi MS, Brown KE, Burge CB, Schmidt WN, Wang Y, McCaffrey AP. Hepatitis C virus infection and hepatic stellate cell activation downregulate miR-29: miR29 overexpression reduces hepatitis $\mathrm{C}$ viral abundance in culture. J Infect Dis. 2011; 203: 1753-62. https://doi. org/10.1093/infdis/jir186.

20. Roderburg C, Urban GW, Bettermann K, Vucur M, Zimmermann H, Schmidt S, Janssen J, Koppe C, Knolle P, Castoldi M, Tacke F, Trautwein C, Luedde T. Micro-RNA profiling reveals a role for miR-29 in human and murine liver fibrosis. Hepatology. 2011; 53: 209-18. https://doi. org/10.1002/hep.23922.

21. Luna JM, Scheel TK, Danino T, Shaw KS, Mele A, Fak JJ, Nishiuchi E, Takacs CN, Catanese MT, de Jong YP, Jacobson IM, Rice CM, Darnell RB. Hepatitis C virus RNA functionally sequesters miR-122. Cell. 2015; 160: 1099110. https://doi.org/10.1016/j.cell.2015.02.025.

22. Murakami Y, Aly HH, Tajima A, Inoue I, Shimotohno K. Regulation of the hepatitis $\mathrm{C}$ virus genome replication by miR-199a. J Hepatol. 2009; 50: 453-60. https://doi. org/10.1016/j.jhep.2008.06.010.

23. Fan Z, Zhang Q, Chen H, He P, Li Y, Si M, Jiao X. Circulating microRNAs as a biomarker to predict therapy efficacy in hepatitis $\mathrm{C}$ patients with different genotypes. Microb Pathog. 2017; 112: 320-6. https://doi.org/10.1016/j. micpath.2017.10.003.

24. Randall G, Panis M, Cooper JD, Tellinghuisen TL, Sukhodolets KE, Pfeffer S, Landthaler M, Landgraf P, Kan $\mathrm{S}$, Lindenbach BD, Chien M, Weir DB, Russo JJ, et al. Cellular cofactors affecting hepatitis $\mathrm{C}$ virus infection and replication. Proc Natl Acad Sci U S A. 2007; 104: 12884-9. https://doi.org/10.1073/pnas.0704894104.

25. Mitchell PS, Parkin RK, Kroh EM, Fritz BR, Wyman SK, Pogosova-Agadjanyan EL, Peterson A, Noteboom J, O'Briant KC, Allen A, Lin DW, Urban N, Drescher CW, et al. Circulating microRNAs as stable blood-based markers for cancer detection. Proc Natl Acad Sci U S A. 2008; 105: 10513-8. https://doi.org/10.1073/pnas.0804549105.

26. Hyrina A, Olmstead AD, Steven P, Krajden M, Tam E, Jean F. Treatment-Induced Viral Cure of Hepatitis C VirusInfected Patients Involves a Dynamic Interplay among three Important Molecular Players in Lipid Homeostasis: Circulating microRNA (miR)-24, miR-223, and Proprotein Convertase Subtilisin/Kexin Type 9. EBioMedicine. 2017; 23: 68-78. https://doi.org/10.1016/j.ebiom.2017.08.020.

27. Jang JY, Lee YS, Jeon YK, Lee K, Jang JJ, Kim CW. ANT2 suppression by shRNA restores miR-636 expression, thereby downregulating Ras and inhibiting tumorigenesis of hepatocellular carcinoma. Exp Mol Med. 2013; 45: e3. https://doi.org/10.1038/emm.2013.1.

28. Miyamoto SD, Karimpour-Fard A, Peterson V, Auerbach SR, Stenmark KR, Stauffer BL, Sucharov CC. Circulating microRNA as a biomarker for recovery in pediatric dilated cardiomyopathy. J Heart Lung Transplant. 2015; 34: 72433. https://doi.org/10.1016/j.healun.2015.01.979.

29. Wang H, Gao H, Duan S, Song X. Inhibition of microRNA$199 \mathrm{a}-5 \mathrm{p}$ reduces the replication of $\mathrm{HCV}$ via regulating the pro-survival pathway. Virus Res. 2015; 208: 7-12. https:// doi.org/10.1016/j.virusres.2015.05.002.

30. Li Q, Lowey B, Sodroski C, Krishnamurthy S, Alao H, Cha H, Chiu S, El-Diwany R, Ghany MG, Liang TJ. Cellular microRNA networks regulate host dependency of hepatitis C virus infection. Nat Commun. 2017; 8: 1789. https://doi. org/10.1038/s41467-017-01954-x. 